
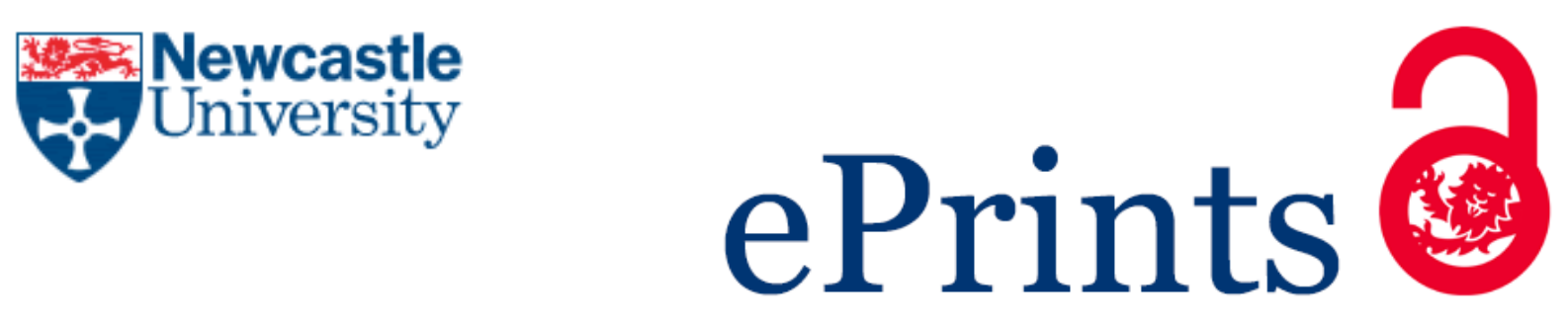

Anic F, Penava D, Sarhosis V.

Development of a three-dimensional computational model for the in-plane and out-of-plane analysis of masonry-infilled reinforced concrete frames. In: 6th International Conference on Computational Methods in Structural Dynamics and Earthquake Engineering (COMPDYN 2017).

15-17 June 2017, Rhodes Island, Greece.

This is the author's manuscript of a paper presented at COMPDYN 2017.

Conference website:

https://2017.compdyn.org/

Date deposited:

$18 / 06 / 2017$ 


\title{
DEVELOPMENT OF A THREE-DIMENSIONAL COMPUTATIONAL MODEL FOR THE IN-PLANE AND OUT-OF-PLANE ANALYSIS OF MASONRY-INFILLED REINFORCED CONCRETE FRAMES
}

\author{
F. Anić ${ }^{1}$, D. Penava ${ }^{1}$, and V. Sarhosis ${ }^{2}$ \\ ${ }^{1}$ Josip Juraj Strossmayer University of Osijek \\ Faculty of Civil Engineering Osijek \\ 3 Vladimir Prelog Street, HR - 31000 Osijek, Republic of Croatia \\ \{fanic, davorin.penava\}@gfos.hr \\ ${ }^{2}$ Newcastle University \\ School of Civil Engineering and Geosciences \\ NE1 7RU, Newcastle upon Tyne, United Kingdom \\ vasilis.sarhosis@newcastle.ac.uk
}

Keywords: Computational modelling, masonry-infilled frames, structural analysis, Atena 3D.

\begin{abstract}
Structural frames, constructed either by steel or reinforced concrete $(R C)$, are often infilled with masonry panels. In design, they are usually treated as non-structural elements, and their interaction with the bounding frame is often ignored. However, recent studies have demonstrated that infilled frame can be superior to a bare frame in terms of stiffness, strength and energy dissipation, when the structure is subjected to strong lateral loads including earthquakes. Today, several models have been developed to evaluate infilled structures. Nevertheless, such models have been validated with limited experimental data, and they have demonstrated different performances when compared with test results. This paper presents the development of a three-dimensional computational model based on the finite element method (FEM) that has been used to study the in-plane and out-of-plane behaviour of masonry infilled RC frames containing openings. Masonry infill walls were modelled as an assemblage of stiff yet deformable bricks while mortar joints as zero thickness interfaces. Initially, the material and interface parameters were determined by carrying out a series of small scale tests. The computational model was then used to predict the in-plane and out-ofplane behaviour of a series of full scale infill wall panels constructed in the laboratory using a similar brick and mortar combination. From the results analysis, it was shown that the FE model was capable of capturing the mode of failure and the load carrying capacity of the masonry-infilled RC frame with sufficient accuracy.
\end{abstract}




\section{INTRODUCTION}

Structural frames, constructed either by reinforced concrete are often infilled with masonry panels/walls. However, in design, the presence of masonry infill for the analysis of the structure is usually ignored. The complexity and interaction mechanism between the masonry infill and the RC frame leads structural engineers to completely disregard this structural component from the analysis [1]. So, it is common practice that the panel and the frame of the structure to be designed separately. However, this results a possible change of the seismic demand due to the significant reduction in the natural period of the composite structural system [2-4]. Also, by doing so, the interaction effect between the two structural components are completely ignored. Recent research [5] demonstrated that the two components complement each other and provide a more efficient structural system. Despite research dating back to the 1950s, there is still lack in the full understanding of the interaction behaviour of masonry infilled steel frames which deem further investigation. Over the last three decades, both full scale experimental testing [6] and various types of computational analyses [7] have been carried out to investigate this interaction and gain a better understanding and representation of the detailed behaviour (i.e. crack patterns) of such systems. Today, there has been a significant development in computational models which have been used for the research of such structural systems. These are becoming increasingly popular due to large costs associated with full-scale experiments and data acquisition systems required to gather all necessary information. However, the biggest hurdle is to identify the correct material parameters to be inputted into masonry constitutive models and produce accurate and reliable models which can simulate the actual behaviour of the structure subjected to various external linear and non-linear loads [8].

So far, it is well understood that an infill wall acts as a diagonal strut connecting the two loaded corners under lateral loads. However, this is a case only applicable when infill walls does not contain any openings (e.g. doors, windows, etc.) interfering the diagonal distribution of stresses. However, there is limited research on the influence of the significance of the location and the size of the opening in infilled frames [9]. Also, masonry infilled RC frames subjected to seismic excitations suffer a combined in- and out-of-plane response. Yet, most calibrated in-plane models are done using 2D methods of analysis where the out-of-plane behaviour of the frame is impossible to be captured and understood. Therefore, the development of accurate 3D micromodel able to predict the in-plane and out-of-plane behaviour of masonry infilled frames is vital.

This paper presents the development of a three-dimensional computational model based on the finite element method (FEM) that has been used to study the in-plane and out-of-plane behaviour of masonry infilled RC frames containing openings. Masonry infill walls were modelled as an assemblage of stiff yet deformable bricks while mortar joints as zero thickness interfaces. Initially, the material and interface parameters were determined by carrying out a series of small scale tests [10]. The computational model was then used to predict the in-plane and out-of-plane behaviour of a full scale infill wall panels constructed in the laboratory using a similar brick and mortar combination. From the results analysis, it was shown that the FE model was capable of capturing the load carrying capacity of the masonry-infilled RC frame as well as the different stages of behaviour from initial crack development, crack propagation at stages of in-creased loading and the mode of failure. 


\section{EXPERIMENTAL TESTING}

Ten masonry infilled RC frames were tested at a scale of 1:2.5 by one of the authors [11]. Frames were designed as medium ductility frames (DCM) in compliance with EN 1992-1-1 [12] and EN 1998-1 [1]. Masonry infill walls was made by Group 2 hollow clay masonry units (Figure 1). Mortar joints were M5 designation according to EN 1996-1-1 [13] and nominal $10 \mathrm{~mm}$ thick. A quasi-static cyclic lateral loading applied at the beam-ends. Each infilled frame specimen was also subjected to vertical pre-compression which applied on top of the columns and was equal to $365 \mathrm{kN}$ (Figure 1). According to DG 3- EMS 98, static pushover loading was applied after large cracks in the infill occurred [14, 23]. A detailed description of the test-rig, the structural material properties, as well as of the loading scheme, can be found in [15].

Six infilled frame configurations were studied in this research. These are presented in Table 1 and include: a) II/1 RC frame without infill; b) II/2 RC frame with full infill; c) I/1 RC frame with centric door opening in the infill; d) I/2 RC frame with centric window opening in the infill; e) I/3 RC frame with eccentric door opening in the infill; and f) I/4 RC frame with eccentric window opening in the infill. Also, in Table $1, A_{o}$ is the area of an opening and is equal to $h_{o} \times l_{o}, A_{i}$ is the area of masonry infill wall and is equal to $h_{i} \times l_{i}, l_{o}$ is the opening length, $h_{o}$ is the opening height, $h_{\mathrm{i}}$ is $1.3 \mathrm{~m}$ and is the infill wall height, $l_{\mathrm{i}}$ is $1.8 \mathrm{~m}$ and is the infill wall length, $e_{\mathrm{o}}$ is the opening eccentricity, $t_{\mathrm{i}}$ is $0.12 \mathrm{~m}$ and is the infill wall thickness and $P$ is the parapet wall height. Experimental testing of the masonry infilled RC frames were divided into three groups. The first group consisted of four masonry infilled RC frames containing an unconfined opening (e.g. door or window) centrically or eccentrically positioned. The second group had vertical tie-column elements around the opening. The third group had two reference specimens, i.e., infilled frames without an opening and a bare reinforced-concrete frame. The opening area $\left(A_{o}\right)$ was selected to be $2.0 \mathrm{~m}^{2}$ which falls within the range (i.e., $A_{o}>1.5 \mathrm{~m}^{2}$ and $A_{o}>2.5 \mathrm{~m}^{2}$ ) defined by EN 1998-1, [16] \& [17].

The experimental test results are presented by the resistance envelope curves (peaks of the second cycles), values of the secant stiffness at characteristic drifts and observed failure mechanisms. Characteristic damage grades of the infilled frame specimens were observed as being $0.1 \%$ for Slight (DG1), 0.2 to 0.3 for Moderate (DG 2), 0.5 for Heavy (DG 3) and $1.0 \%$ for Pre-collapse (DG 4). These damage grades are in compliance with the EMS-98 damage scale [14], and they occurred at the masonry infill. Also, the experimental tests showed that there were two notable features of the behaviour of the masonry infill walls with and without openings. First, bed-joint sliding above the opening observed. This was due to weakened horizontal planes caused by the presence of the opening. Then, diagonal tensile or bed-joint sliding failure occurred at the masonry piers. 

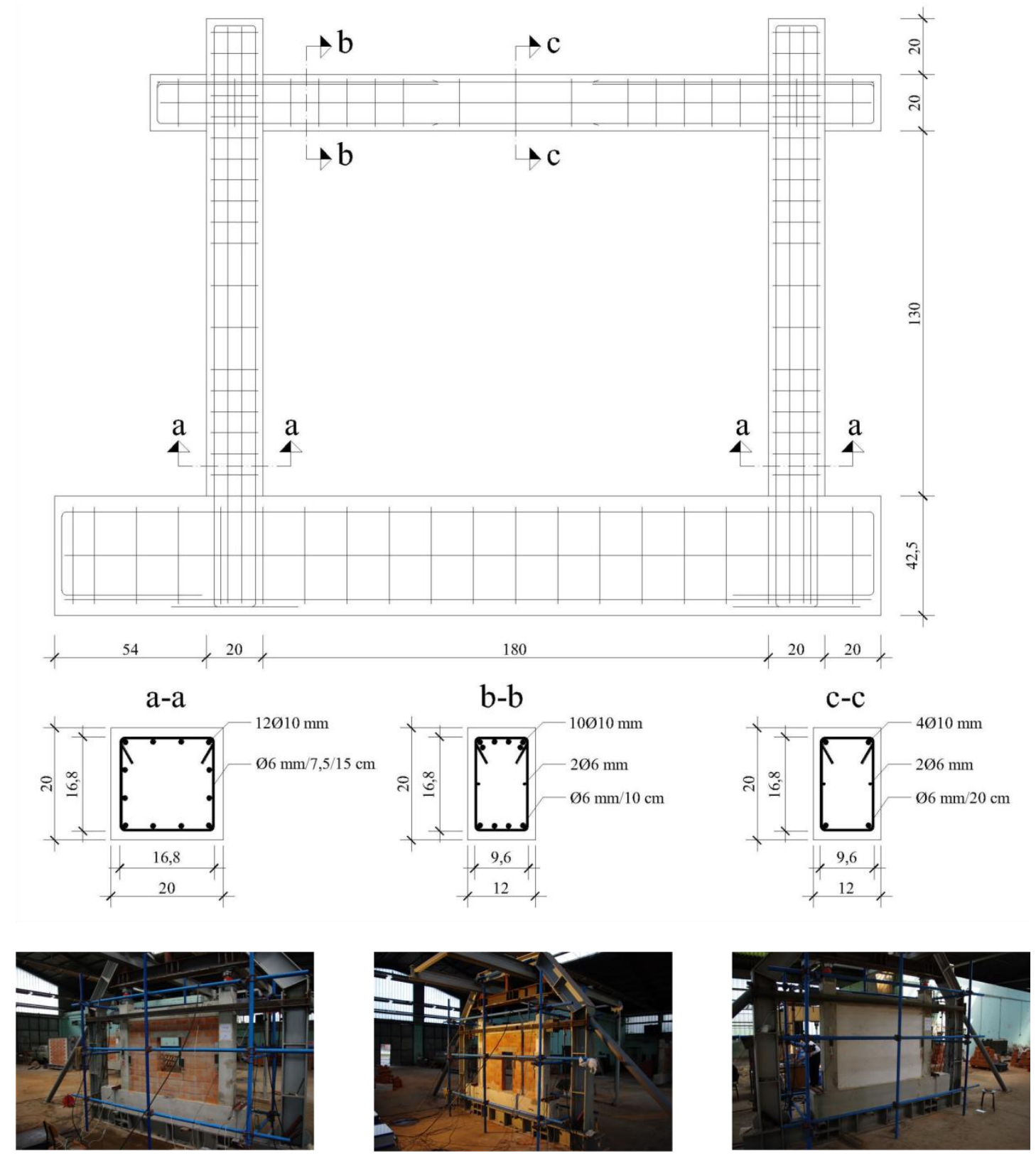

Figure 1: Tested infilled frames [11, 15]

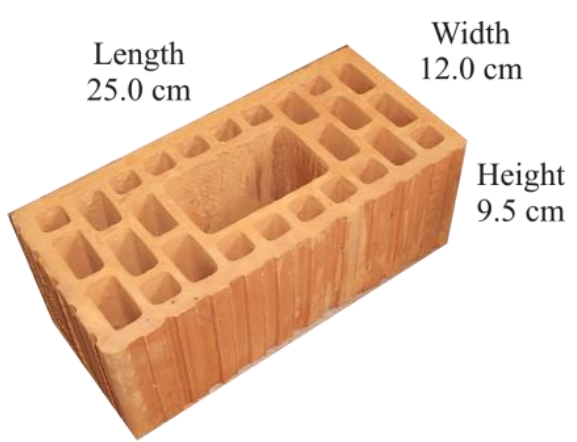

Figure 2: Hollow clay block used 
By comparing the measured resistance envelope curves between the infilled frames and the bare frame, significant increases in secant stiffness and a load carrying capacity of up to three times have been observed.

\begin{tabular}{|c|c|c|c|c|c|}
\hline \multicolumn{2}{|c|}{ Specimen } & \multirow{2}{*}{$\begin{array}{l}\text { Appearance of the } \\
\text { specimen }\end{array}$} & \multicolumn{2}{|c|}{ Opening } & \multirow{2}{*}{ Description } \\
\hline Group & Mark & & Type and area & Position & \\
\hline \multirow{16}{*}{ I } & \multirow{4}{*}{1} & & \multirow{4}{*}{$\begin{array}{c}\text { Door } \\
l_{\mathrm{o}} / h_{\mathrm{o}}=0.35 / 0.90 \mathrm{~m} \\
A_{\mathrm{o}}=0.32 \mathrm{~m}^{2} \\
A_{\mathrm{o}} / A_{\mathrm{i}}=0,14\end{array}$} & \multirow{4}{*}{$\begin{array}{c}\text { Centric } \\
e_{\mathrm{o}}=l_{\mathrm{i}} / 2=0.90 \mathrm{~m}\end{array}$} & \multirow{16}{*}{ 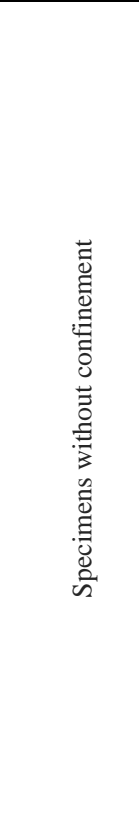 } \\
\hline & & & & & \\
\hline & & & & & \\
\hline & & & & & \\
\hline & \multirow{4}{*}{2} & & \multirow{4}{*}{$\begin{array}{c}\text { Window } \\
l_{\mathrm{o}} / h_{\mathrm{o}}=50.0 / 60.0 \mathrm{~cm} \\
A_{\mathrm{o}}=0.30 \mathrm{~m}^{2} \\
A_{\mathrm{o}} / A_{\mathrm{i}}=0,13\end{array}$} & \multirow{4}{*}{$\begin{array}{c}\text { Centric } \\
e_{0}=l_{\mathrm{i}} / 2=0.90 \mathrm{~m} \\
P=0.40 \mathrm{~m}\end{array}$} & \\
\hline & & $\square$ & & & \\
\hline & & & & & \\
\hline & & & & & \\
\hline & \multirow{4}{*}{3} & 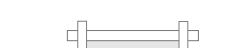 & \multirow{4}{*}{$\begin{array}{c}\text { Door } \\
l_{\mathrm{o}} / h_{\mathrm{o}}=0.35 / 0.90 \mathrm{~m} \\
A_{\mathrm{o}}=0.32 \mathrm{~m}^{2} \\
A_{\mathrm{o}} / A_{\mathrm{i}}=0,14\end{array}$} & \multirow{4}{*}{$\begin{array}{c}\text { Eccentric } \\
\mathrm{e}_{0}=h_{\mathrm{i}} / 5+l_{\mathrm{o}} / 2=0.44 \mathrm{~m}\end{array}$} & \\
\hline & & & & & \\
\hline & & & & & \\
\hline & & & & & \\
\hline & \multirow{4}{*}{4} & & Window & Eccentric & \\
\hline & & एा & \multirow{3}{*}{$\begin{array}{c}l_{\mathrm{o}} / h_{\mathrm{o}}=50.0 / 60.0 \mathrm{~cm} \\
A_{\mathrm{o}}=0.30 \mathrm{~m}^{2} \\
A_{\mathrm{o}} / A_{\mathrm{i}}=0,13\end{array}$} & \multirow{3}{*}{$\begin{array}{c}e_{\mathrm{o}}=h_{\mathrm{i}} / 5+l_{\mathrm{o}} / 2=0.44 \mathrm{~m} \\
P=0.40 \mathrm{~m}\end{array}$} & \\
\hline & & & & & \\
\hline & & & & & \\
\hline \multirow{3}{*}{ II } & 1 & & - & - & \multirow{3}{*}{ 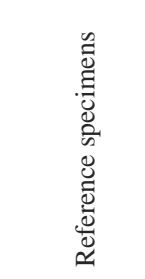 } \\
\hline & & & & & \\
\hline & 2 & & - & - & \\
\hline
\end{tabular}

Table 1: Classification and description of the specimens

\section{COMPUTATIONAL MODELLING OF MASONRY INFILLED FRAMES}

Three dimensional computational models representing bare and masonry infilled RC frames tested in the laboratory were developed using the Atena3D software [18]. Concrete frame, lintel, steel plates and masonry units were modelled using 3D solid constituents. Also, concrete rebar modelled by 1D truss elements with perfect bond assigned to the concrete. Mortar joints were modelled as a zero thickness interfaces. The modelling constituents and boundary conditions used in the analyses are shown at Figure 3. A mesh size of $4 \mathrm{~cm}$ was used for the analysis [10]. CCIsoTetra mesh elements were used for steel plates while CCIsoBrick was used for all the other elements of the masonry infilled RC frame. 


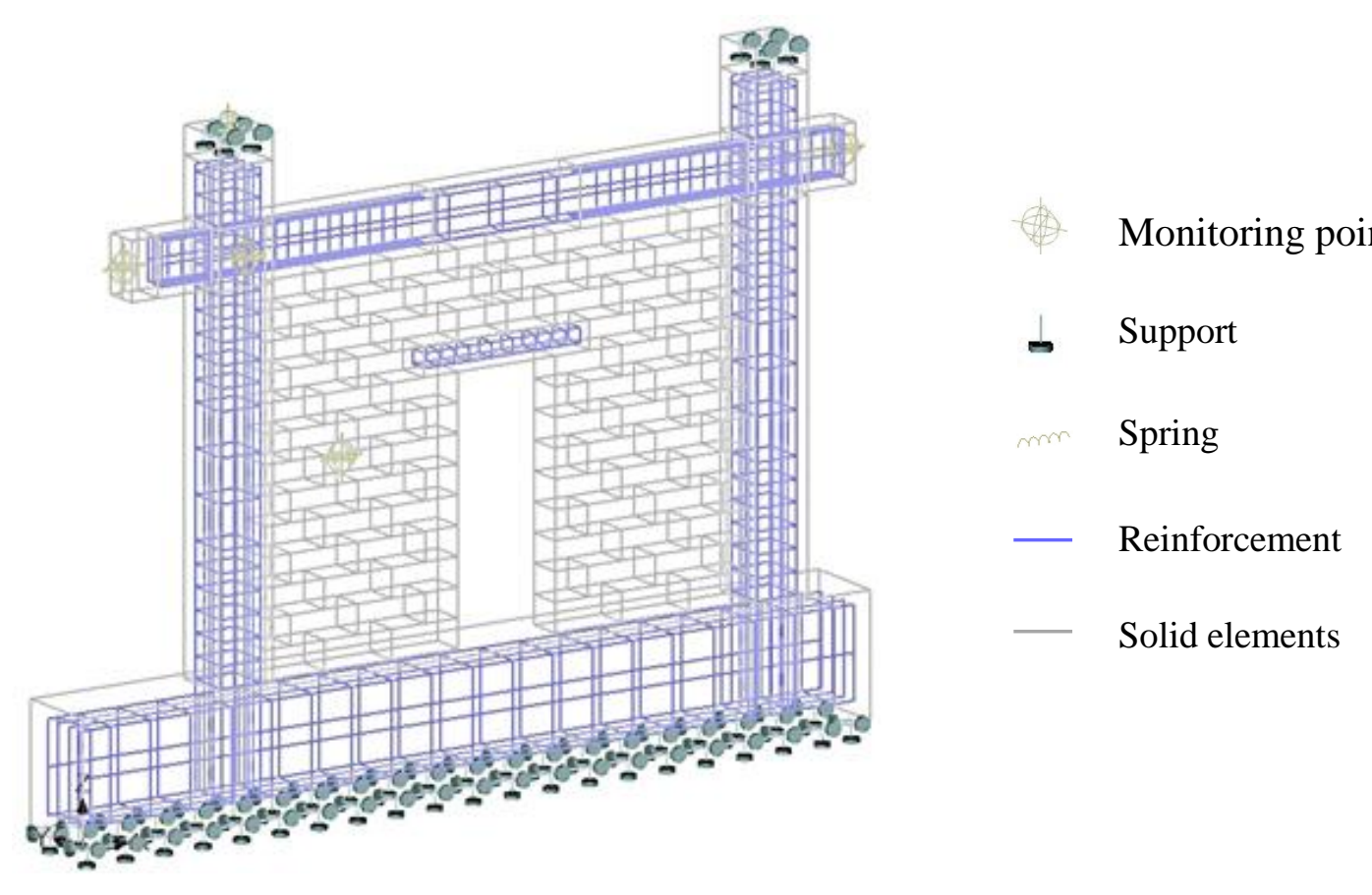

Figure 3: Typical infilled frame developed in Atena 3D (Case I/1)

A constant pre-compression equal to $365 \mathrm{kN}$ assigned at the column ends. Due to large vertical pre-compression, friction could not be undermined. Friction coefficient for sliding the steel roller $\left(\mu_{F}\right)$ was taken as 0.03 [19]. Hence, the friction force $\left(T_{F}\right)$ for one column end was calculated using eq. 1 .

$$
T_{F}=\mu_{F} \times 365 \approx 10 \mathrm{kN}
$$

For introducing friction force onto the numerical model, a non-linear surface spring was set on the beams end on the opposite side of the in-plane applied loading. Spring stiffness calculated by eq. 2 .

$$
K_{s}=\frac{2 T_{F}}{A_{\text {beam }}}=0.83 \mathrm{MPa}
$$

Figure $4 \mathrm{~b}$ shows the spring's non-linear relationship. The concrete frame, lintel and masonry units simulated using " $3 D$ non-linear cementitious" material model (Table 1). Reinforcement simulated using the "bilinear reinforcement" material model shown in Table 2 and the mortar joints simulated using the " $3 D$ interface" material model (Table 3). Material model parameters were adopted from [10] and are described in detail in [20]. 


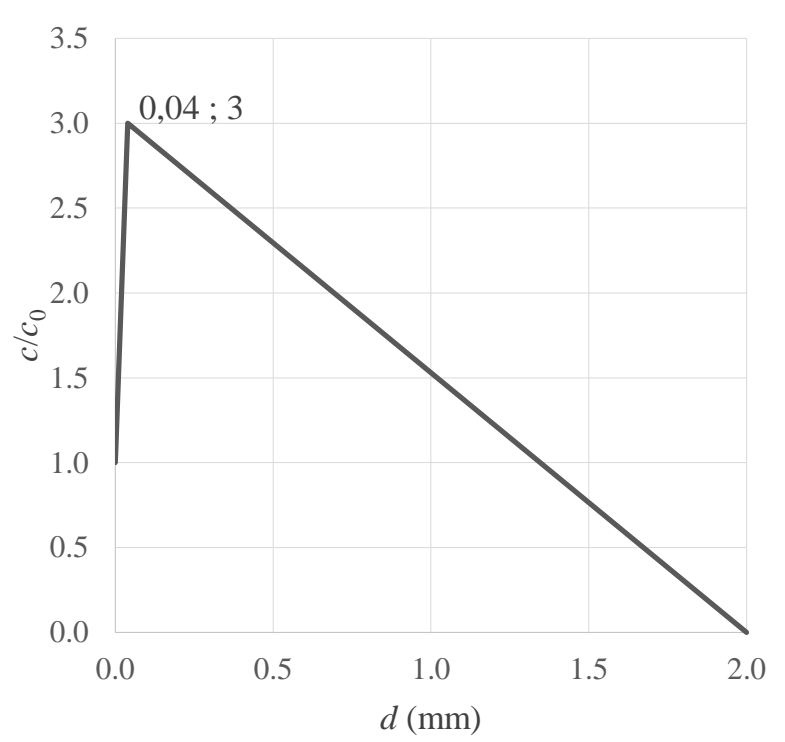

a) Mortar interlock

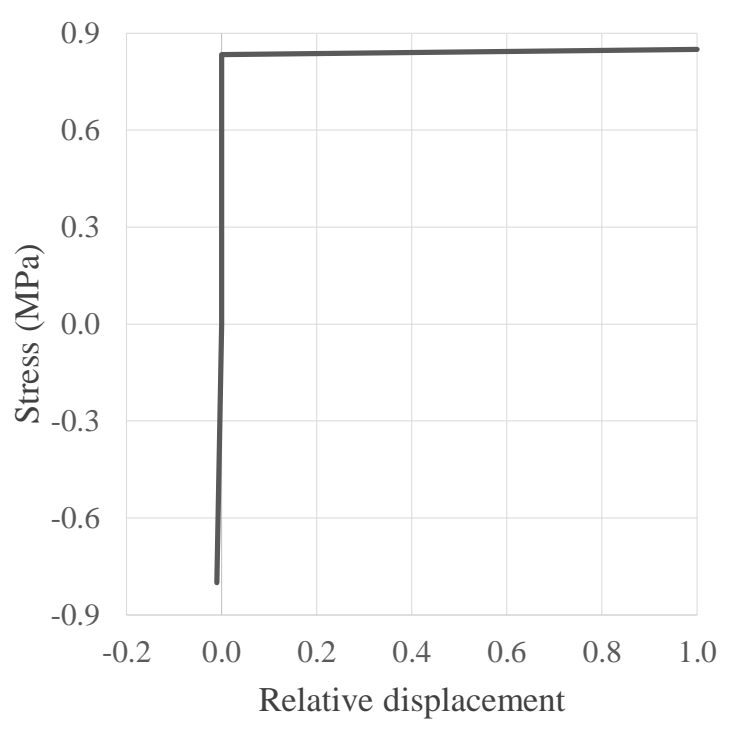

b) Spring non-linear function

Figure 4 Material functions

\begin{tabular}{llcccl}
\hline \multicolumn{1}{c}{ Description } & Symbol & $\begin{array}{c}\text { Frame concrete } \\
\text { Value }\end{array}$ & $\begin{array}{c}\text { Concrete lintel } \\
\text { Value }\end{array}$ & $\begin{array}{c}\text { Clay block } \\
\text { Value }\end{array}$ & Unit \\
\hline Elastic modulus & $E$ & $4.100 \mathrm{E}+04$ & $3.032 \mathrm{E}+04$ & $5.650 \mathrm{E}+03$ & $\mathrm{MPa}$ \\
Poisson's ratio & $\mu$ & 0.200 & 0.200 & 0.100 & $/$ \\
Tensile strength & $f_{\mathrm{t}}$ & 4.000 & 2.317 & 1.800 & $\mathrm{MPa}$ \\
Compressive strength & $f_{\mathrm{c}}$ & $-5.800 \mathrm{E}+01$ & $-2.550 \mathrm{E}+01$ & $-1.750 \mathrm{E}+01$ & $\mathrm{MPa}$ \\
Specific fracture energy & $G_{\mathrm{f}}$ & $1.200 \mathrm{E}-04$ & $5.739 \mathrm{E}-05$ & $4.500 \mathrm{E}-04$ & $\mathrm{MN} / \mathrm{m}$ \\
Crack spacing & $S_{\max }$ & 0.125 & 0.125 & $-5.000 \mathrm{E}-04$ & $\mathrm{~m}$ \\
Tensile stiffening & $c_{\mathrm{ts}}$ & 0.400 & 0.400 & $-1.358 \mathrm{E}-03$ & $/$ \\
Critical compressive disp. & $W_{\mathrm{d}}$ & $-1.010 \mathrm{E}-03$ & $-5.000 \mathrm{E}-04$ & $/$ & $/$ \\
Plastic strain at $f_{\mathrm{c}}$ & $\varepsilon_{\mathrm{cp}}$ & $-1.417 \mathrm{E}-03$ & $-8.411 \mathrm{E}-04$ & $/$ & $/$ \\
Reduction of $f_{\mathrm{c}}$ due to cracks & $r_{\mathrm{c} \text {.lim }}$ & 0.800 & 0.800 & 0.800 & $/$ \\
Crack shear stiffness factor & $S_{\mathrm{F}}$ & 20.000 & 20.000 & 20.000 & $/$ \\
Aggregate size & & $1.600 \mathrm{E}-02$ & $2.000 \mathrm{E}-02$ & $/$ & $\mathrm{m}$ \\
Fixed crack model coefficient & & 1.000 & 1.000 & 1.000 & $/$ \\
\hline
\end{tabular}

Table 1: Non-linear cementitious 2 material properties for each constituent

\begin{tabular}{llll}
\hline Description & Symbol & Value & Unit \\
\hline Elastic modulus & $E$ & $2.10 \mathrm{E}+05$ & $\mathrm{MPa}$ \\
Yield strength & $\sigma_{\mathrm{y}}$ & $5.50 \mathrm{E}+02$ & $\mathrm{MPa}$ \\
Tensile strength & $\sigma_{\mathrm{t}}$ & $6.50 \mathrm{E}+02$ & $\mathrm{MPa}$ \\
Limited ductility of steel & $\varepsilon_{\text {lim }}$ & 0.01 & $/$ \\
\hline
\end{tabular}

Table 2: Bilinear steel reinforcement material properties 


\begin{tabular}{|c|c|c|c|c|}
\hline \multirow[t]{2}{*}{ Description } & \multirow[t]{2}{*}{ Symbol } & Mortat bedjoint & $\begin{array}{l}\text { Mortar head- } \\
\text { joint }\end{array}$ & \multirow[t]{2}{*}{ Unit } \\
\hline & & Value & Value & \\
\hline Normal stiffness & $K_{\mathrm{nn}}$ & $5.65 \mathrm{E}+05$ & $8.50 \mathrm{E}+04$ & $\mathrm{MN} / \mathrm{m}^{2}$ \\
\hline Min. normal stiffness & $K_{\text {nn.min }}$ & $5.65 \mathrm{E}+02$ & $8.50 \mathrm{E}+01$ & $\mathrm{MN} / \mathrm{m}^{2}$ \\
\hline Tangential stiffness & $K_{\mathrm{tt}}$ & $2.57 \mathrm{E}+05$ & $3.86 \mathrm{E}+04$ & $\mathrm{MN} / \mathrm{m}^{2}$ \\
\hline Min. tangential stiffness & $K_{\mathrm{tt} . \min }$ & $2.57 \mathrm{E}+02$ & $3.86 \mathrm{E}+01$ & $\mathrm{MN} / \mathrm{m}^{2}$ \\
\hline Tensile strength & $f_{\mathrm{t}}$ & 0.20 & 0.20 & $\mathrm{MPa}$ \\
\hline Cohesion & $c$ & 0.35 & 0.35 & $\mathrm{MPa}$ \\
\hline Friction coefficient & & 0.24 & 0.24 & l \\
\hline Interlock function & & see fig. $1 \mathrm{a}$ & I & \\
\hline
\end{tabular}

Table 3: Interface material properties

According to Eurocode 8 [1], the allowable minimum damage $\left(d_{\mathrm{r}}\right)$ for no-collapse scenario for non-structural elements ( $3^{\text {rd }}$ Class) made of brittle materials can be estimated by $0.10 \mathrm{~h}$; where $h$ is the height of the specimen. In favour of satisfying the stated requirement with the specimen's height of $140 \mathrm{~cm}$, the inter-storey drift ratio $\left(d_{\mathrm{r}}\right)$ has to be $\leq 14 \mathrm{~mm}$. Thus, during the numerical simulations, all frames were allowed to deform up to $28 \mathrm{~mm}\left(\right.$ e.g. $\left.2 \times d_{\mathrm{r}}\right)$ so that the $1 \% d_{\mathrm{r}}$ to be evaluated. Furthermore, depending on the location of the application of the monotonic load, frames with eccentric openings would behave differently mechanically. Subsequently, two additional models were developed for the case I/3 (e.g. I/3a \& I/3b) and two for the case I/4 (e.g. I/4a \& I/4b). All loads were applied as point loads onto the steel plates. It should be mentioned that steel plates had enough thickness to neglect St. Venant's principle and a perfect connection to the frame. Vertical load was applied in 5 steps (i.e. 73 $\mathrm{kN}$ per step). Horizontal forces applied as a prescribed deformation of $0.20 \mathrm{~mm}$ in 140 steps to achieve a total displacement equal to $28 \mathrm{~mm}$.

\section{RESULTS AND DISCUSSION}

Figure $5 \& 6$ show the computational and experimental values with respect to displacement $(d)$, drift ratio $\left(d_{\mathrm{r}}\right)$, shear force $\left(V_{\mathrm{R}}\right)$ and shear force ratio $\left(V_{\mathrm{R}} / V_{\mathrm{R} \cdot \max }\right)$. A shear force ratio equal to 1.0 allowed for the maximum experimental shear force value $\left(V_{\text {R.max }}\right)$.

Figure 5 shows the crack pattern and minimal principal stresses for in-plane deformations in the order of $28 \mathrm{~mm}$. The minimal crack width was $0.1 \mathrm{~mm}$ [21]. Hairline cracks are in the order of $0.1 \mathrm{~mm}$ and in many cases represent insignificant damage. However, according to [22, 23], hairline cracks can signal moderate or higher level of damage. Also, Table 5 presents a comparison of the $V_{\mathrm{R}} / d$ and the drift ratio. In Table 5, the deviation of computational against the experimental results calculated using the eq. 3 .

$$
\Delta=1-\frac{\text { Computational value }}{\text { Experimental value }}
$$

From Table 5 and Figures $5 \& 6$, we can conclude that:

a) The response of monotonic static and cyclic quasi - static models (Figure $6 \&$ Table 5) are within expected range [16] especially with regards to initial stiffness. Large differences occurred after cyclic quasi - static models reached plasticity as monotonic static models have a greater bearing capacity [16]. Plasticity in cyclic quasi-static models 
develops around $0.25 \% d_{r}$ and around 4 times larger i.e. $1.25 \% d_{r}$ for the monotonic static models (Figure 6).

b) From Figure 7 and for all models, the failure mechanism can be characterized by a shear development in the toe area, damage at the frame and in the diagonal of the masonry infill.

c) The differences between computational models with eccentric openings ( $/ / 3 \mathrm{a} \& \mathrm{I} / 3 \mathrm{~b}$, $\mathrm{I} / 4 \mathrm{a} \& \mathrm{I} / 4 \mathrm{~b}$ ) loaded from different ends are not extensive as the average difference in stiffness is $8 \%$ (Table 5).

d) The positive and negative experimental cyclic results differ by $15 \%$ on average. In some cases (e.g. the stiffness of I/1 model at $0.50 \% d_{r}$ ), the difference could be in the order of $52 \%$ (Table 5). Consequently, the monotonic static model results are in majority of cases between the positive and negative curve (Figure 6) with a larger tendency to the positive curve.

e) Considering the large variability of masonry constituents [10,11], the developed model based on the micro-scale modelling approach was able to capture the experimental behaviour of the masonry infill RC frame with sufficient accuracy.

f) The model was subjected to nonlinear static (monotonic) loading and the results comparison with experimental data showed high quality compatibility in failure mechanism description and response in initial stage. As anticipated, after the initial stage the model showed higher response resistance. 


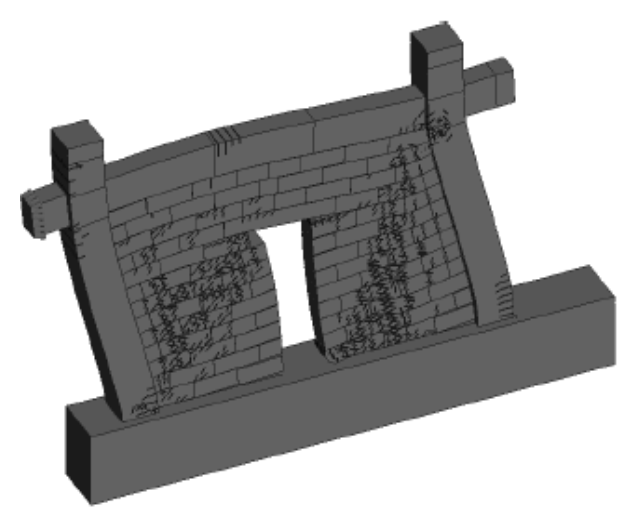

(a) Crack pattern I/1 model

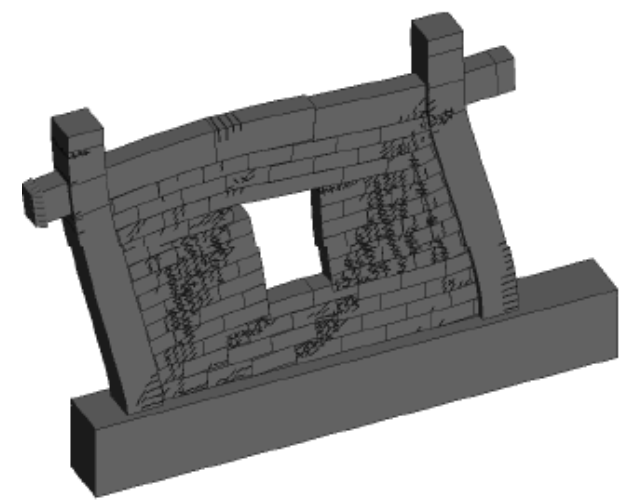

(c) Crack pattern I/2 model

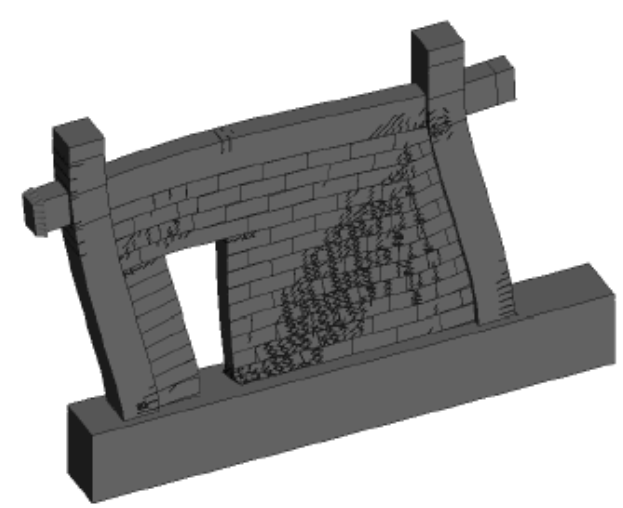

(e) Crack pattern I/3a model

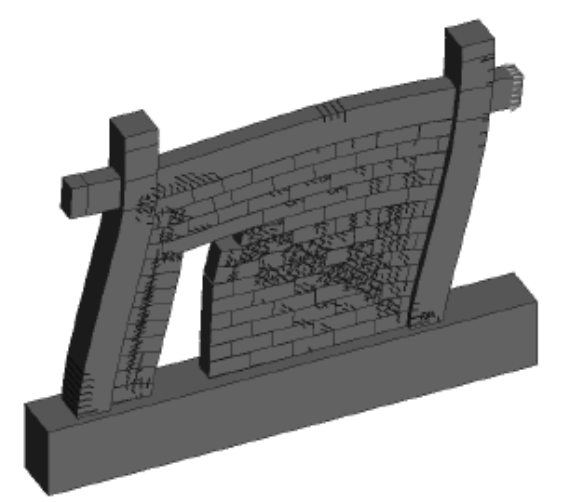

(g) Crack pattern I/3b model

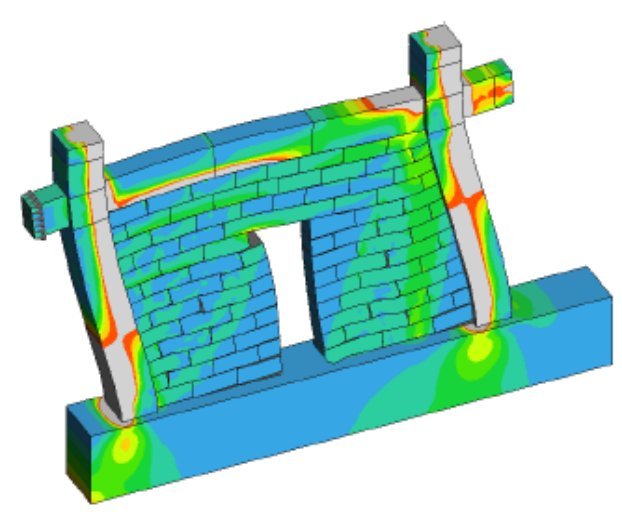

(b) Min. principal stress isolines I/1 model

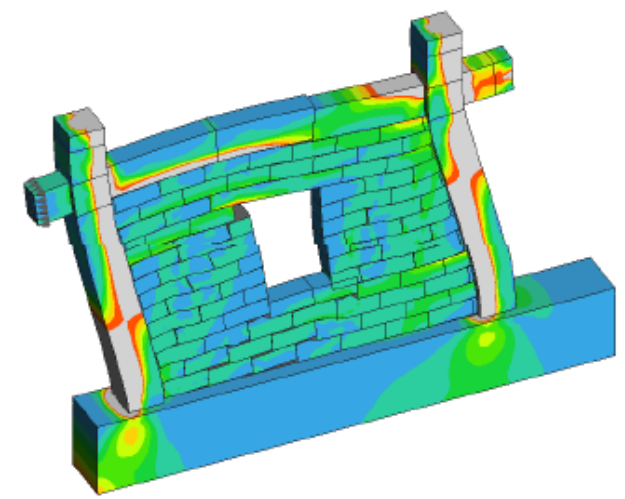

(d) Min. principal stress isolines I/3a model

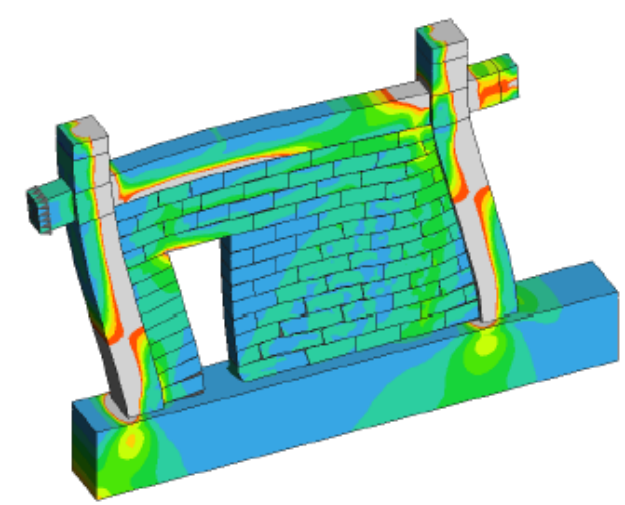

(f) Min. principal stress isolines I/3a model

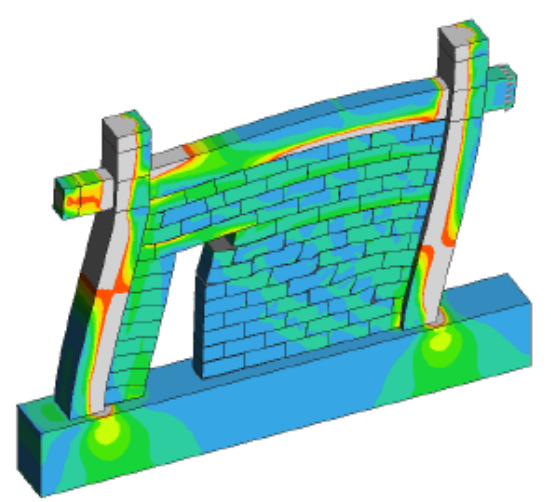

(h) Min. principal stress isolines I/1b model 


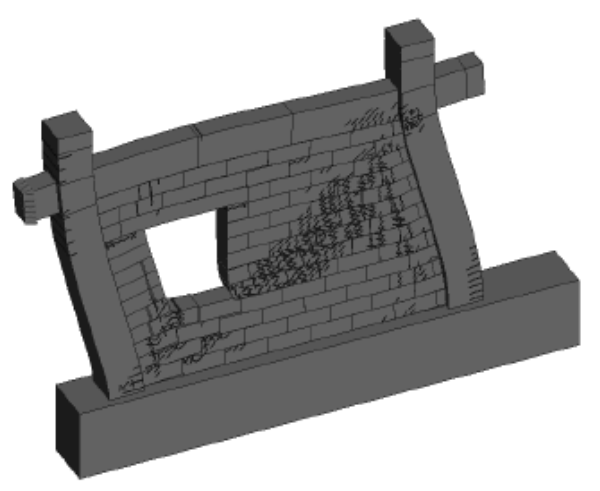

(i) Crack pattern I/4a model

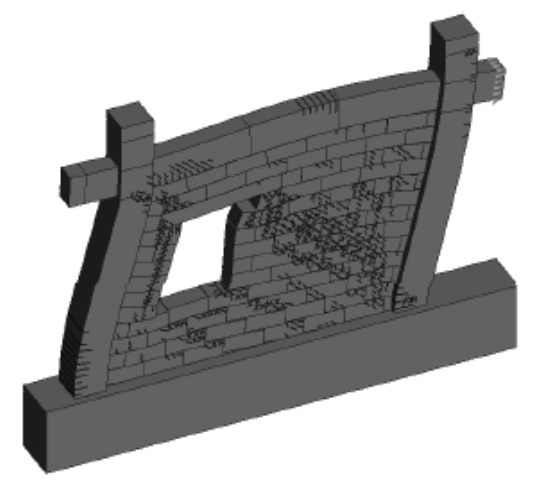

(k) Crack pattern I/4b model

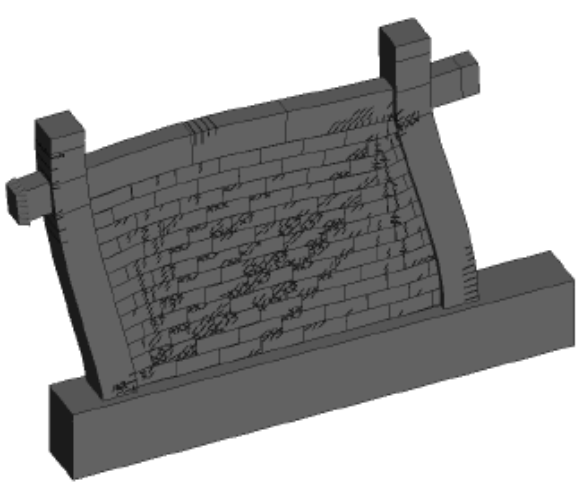

(m) Crack pattern III/2 model

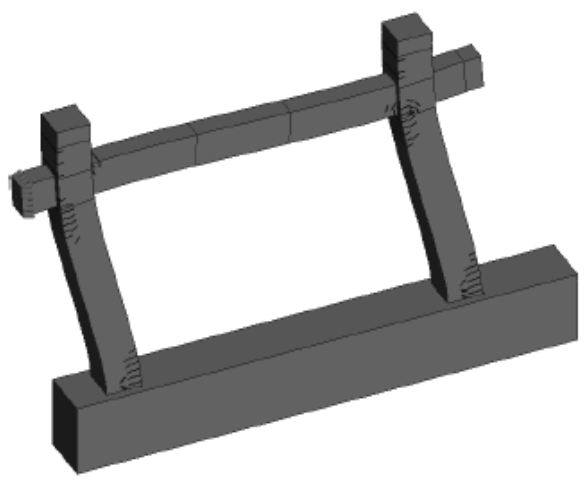

(o) Crack pattern III/1 model

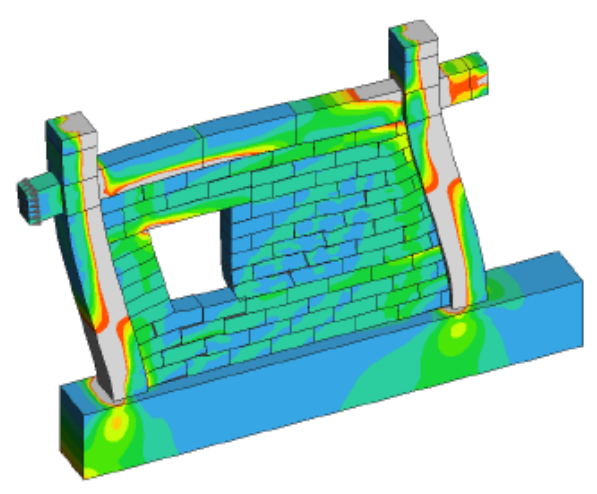

(j) Min. principal stress isolines I/4a model

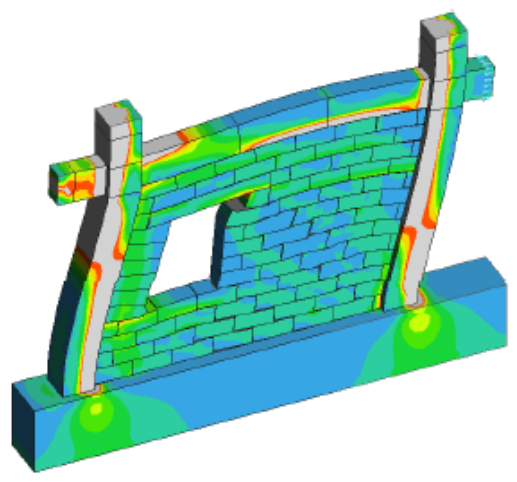

(l) Min. principal stress isolines I/4b model

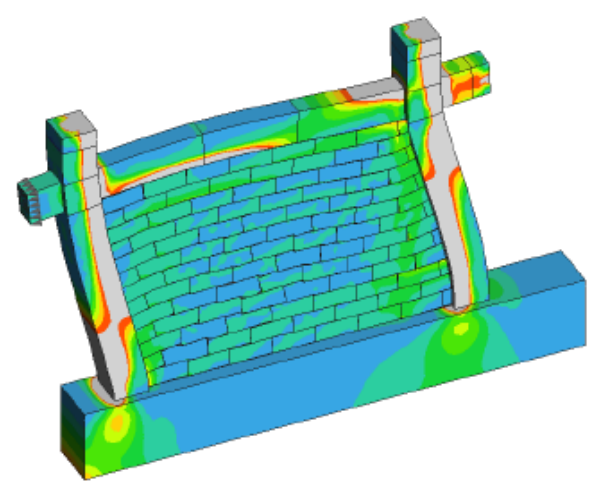

(n) Min. principal stress isolines III/2 model

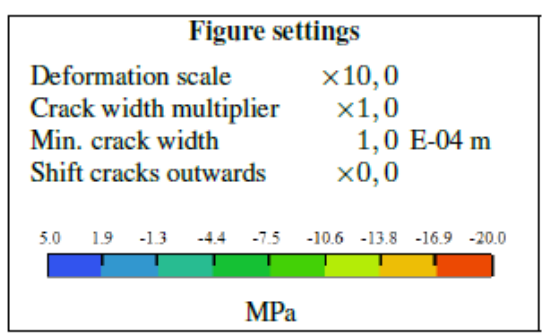

Figure 5: Principal stress and crack patterns for the models developed by Atena 3D software (deformation at 28 $\mathrm{mm}$ ) 

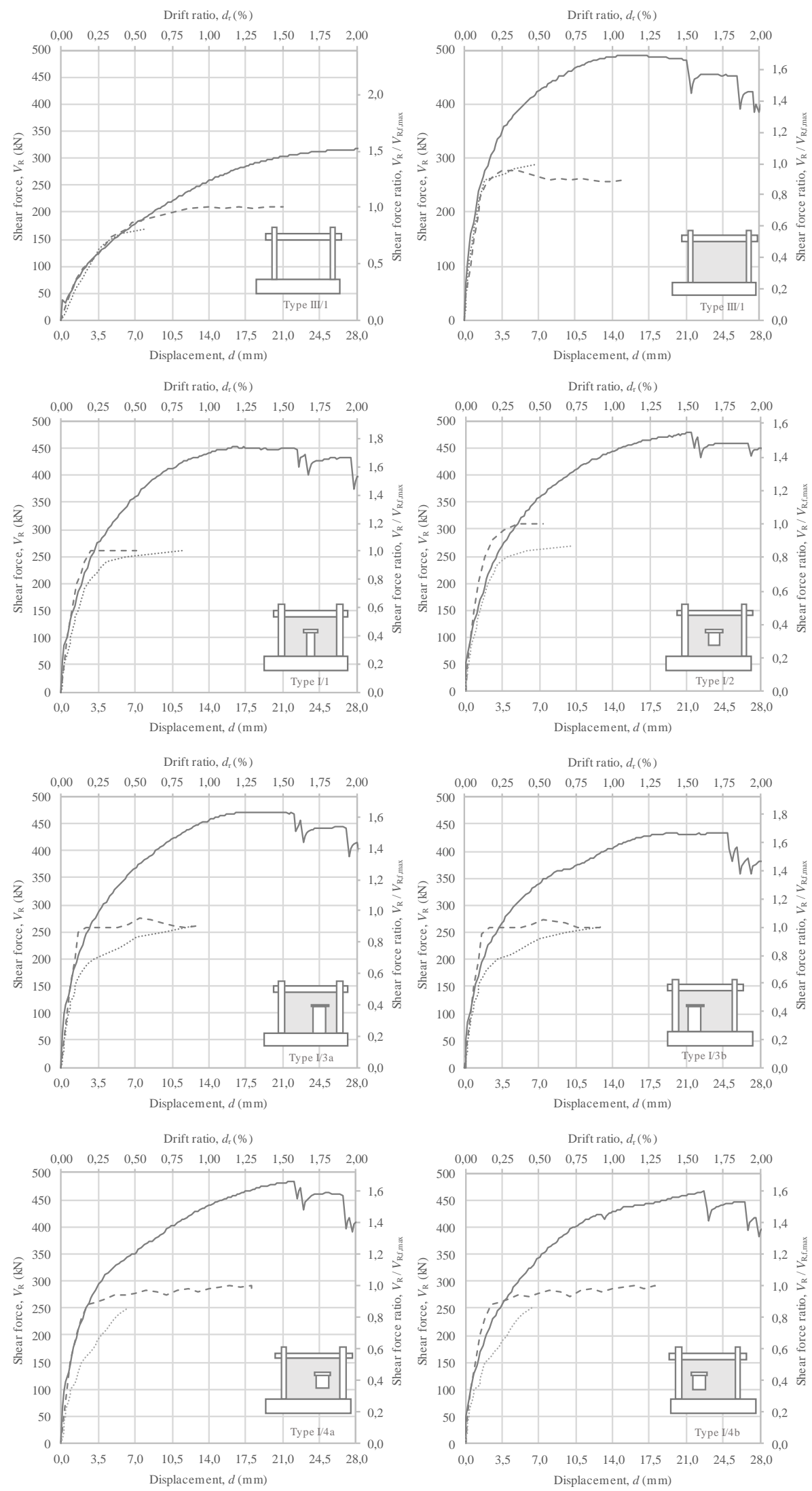

- - - - - Experiment (cyclic -positive

Compulations (static)

Experimental (cyclic-negative)

Figure 6: Comparison of experimental and numerical shear force vs displacement curves 
Filip Anić, Davorin Penava and Vasilis Sarhosis

\begin{tabular}{|c|c|c|c|c|c|c|c|c|c|c|c|c|c|c|c|c|c|c|}
\hline \multirow{3}{*}{$\begin{array}{l}\text { Test } \\
\text { type }\end{array}$} & \multirow{3}{*}{$\begin{array}{c}\text { Storey } \\
\text { drift } \\
\text { ratio }\end{array}$} & \multicolumn{8}{|c|}{ Stiffnes $\left(V_{\mathrm{R}} / d\right)$ by model type $(\mathrm{kN} / \mathrm{mm})$} & & \multicolumn{8}{|c|}{ Difference from the computational model (\%) } \\
\hline & & \multirow{2}{*}{$\mathrm{I} / 1$} & \multirow{2}{*}{$\mathrm{I} / \mathrm{II}$} & \multirow{2}{*}{ III/1 } & \multirow{2}{*}{ III/2 } & \multicolumn{2}{|c|}{$\mathrm{I} / 3$} & \multicolumn{2}{|c|}{$\mathrm{I} / 4$} & & \multirow{2}{*}{$\mathrm{I} / 1$} & \multirow{2}{*}{$\mathrm{I} / \mathrm{II}$} & \multirow{2}{*}{ III/1 } & \multirow{2}{*}{$\mathrm{III} / 2$} & \multicolumn{2}{|c|}{$\mathrm{I} / 3$} & \multicolumn{2}{|c|}{$\mathrm{I} / 4$} \\
\hline & & & & & & a & $\mathrm{b}$ & a & $\mathrm{b}$ & & & & & & a & $\mathrm{b}$ & a & $\mathrm{b}$ \\
\hline \multirow{6}{*}{ 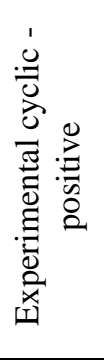 } & 0.25 & 74.29 & 83.68 & 35.29 & 77.72 & \multicolumn{2}{|c|}{73.85} & \multicolumn{2}{|c|}{75.23} & \multirow{6}{*}{ 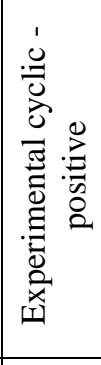 } & -7.36 & 7.04 & -1.42 & -26.79 & -8.53 & -3.84 & -9.33 & 2.37 \\
\hline & 0.50 & 74.29 & 44.22 & 25.98 & 36.71 & 38. & & & & & 30.54 & -15.54 & 1.51 & -66.26 & -34.65 & -25.39 & -27.63 & -23.11 \\
\hline & 0.75 & $\mathrm{n} / \mathrm{a}$ & $\mathrm{n} / \mathrm{a}$ & 19.00 & 24.77 & 24. & & & & & $\mathrm{n} / \mathrm{a}$ & $\mathrm{n} / \mathrm{a}$ & -10.50 & -79.81 & -64.58 & -45.57 & -45.14 & -45.00 \\
\hline & 1.00 & $\mathrm{n} / \mathrm{a}$ & $\mathrm{n} / \mathrm{a}$ & 14.90 & 18.37 & $\mathrm{n} /$ & & & & & $\mathrm{n} / \mathrm{a}$ & $\mathrm{n} / \mathrm{a}$ & -23.34 & -88.82 & \multicolumn{2}{|c|}{$\mathrm{n} / \mathrm{a}$} & -53.58 & -49.39 \\
\hline & 1.50 & $\mathrm{n} / \mathrm{a}$ & $\mathrm{n} / \mathrm{a}$ & 9.94 & $\mathrm{n} / \mathrm{a}$ & $\mathrm{n} /$ & & & & & $\mathrm{n} / \mathrm{a}$ & $\mathrm{n} / \mathrm{a}$ & -44.95 & $\mathrm{n} / \mathrm{a}$ & \multicolumn{2}{|c|}{$\mathrm{n} / \mathrm{a}$} & \multicolumn{2}{|c|}{$\mathrm{n} / \mathrm{a}$} \\
\hline & 2.00 & $\mathrm{n} / \mathrm{a}$ & $\mathrm{n} / \mathrm{a}$ & $\mathrm{n} / \mathrm{a}$ & $\mathrm{n} / \mathrm{a}$ & \multicolumn{2}{|c|}{$\mathrm{n} / \mathrm{a}$} & \multicolumn{2}{|c|}{$\mathrm{n} / \mathrm{a}$} & & $\mathrm{n} / \mathrm{a}$ & $\mathrm{n} / \mathrm{a}$ & $\mathrm{n} / \mathrm{a}$ & $\mathrm{n} / \mathrm{a}$ & \multicolumn{2}{|c|}{$\mathrm{n} / \mathrm{a}$} & \multicolumn{2}{|c|}{$\mathrm{n} / \mathrm{a}$} \\
\hline \multirow{6}{*}{ 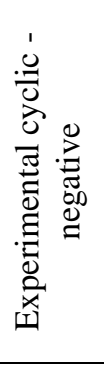 } & 0.25 & 66.15 & 69.47 & 36.59 & 77.14 & \multicolumn{2}{|c|}{57.91} & & & & -20.56 & -11.98 & 2.20 & -27.74 & -38.41 & -32.42 & -49.24 & -33.26 \\
\hline & 0.50 & 35.95 & 37.50 & 23.71 & $\mathrm{n} / \mathrm{a}$ & 34. & & & & 总。 & -43.53 & -36.23 & -7.90 & $\mathrm{n} / \mathrm{a}$ & -52.45 & -41.97 & $\mathrm{n} /$ & \\
\hline & 0.75 & 24.51 & $\mathrm{n} / \mathrm{a}$ & $\mathrm{n} / \mathrm{a}$ & $\mathrm{n} / \mathrm{a}$ & 24. & & & & 预: & -59.59 & $\mathrm{n} / \mathrm{a}$ & $\mathrm{n} / \mathrm{a}$ & $\mathrm{n} / \mathrm{a}$ & -67.61 & -48.24 & $11 \mathrm{t}$ & \\
\hline & 1.00 & $\mathrm{n} / \mathrm{a}$ & $\mathrm{n} / \mathrm{a}$ & $\mathrm{n} / \mathrm{a}$ & $\mathrm{n} / \mathrm{a}$ & $\mathrm{n} /$ & & & & 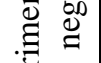 & $\mathrm{n} / \mathrm{a}$ & $\mathrm{n} / \mathrm{a}$ & $\mathrm{n} / \mathrm{a}$ & $\mathrm{n} / \mathrm{a}$ & $\mathrm{n} / \mathrm{a}$ & $\mathrm{n} / \mathrm{a}$ & IIt & \\
\hline & 1.50 & $\mathrm{n} / \mathrm{a}$ & $\mathrm{n} / \mathrm{a}$ & $\mathrm{n} / \mathrm{a}$ & $\mathrm{n} / \mathrm{a}$ & $\mathrm{n} /$ & & & & 这 & $\mathrm{n} / \mathrm{a}$ & $\mathrm{n} / \mathrm{a}$ & $\mathrm{n} / \mathrm{a}$ & $\mathrm{n} / \mathrm{a}$ & $\mathrm{n} / \mathrm{a}$ & $\mathrm{n} / \mathrm{a}$ & 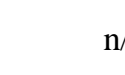 & \\
\hline & 2.00 & $\mathrm{n} / \mathrm{a}$ & $\mathrm{n} / \mathrm{a}$ & $\mathrm{n} / \mathrm{a}$ & $\mathrm{n} / \mathrm{a}$ & $\mathrm{n} /$ & & & & & $\mathrm{n} / \mathrm{a}$ & $\mathrm{n} / \mathrm{a}$ & $\mathrm{n} / \mathrm{a}$ & $\mathrm{n} / \mathrm{a}$ & $\mathrm{n} / \mathrm{a}$ & $\mathrm{n} / \mathrm{a}$ & $\mathrm{n} /$ & \\
\hline & 0.25 & 79.75 & 77.79 & 35.79 & 98.54 & 80.16 & 76.69 & 82.25 & 73.44 & 0 & 13.96 & 2.47 & 0.39 & 27.26 & 23.47 & 18.13 & 29.29 & 15.44 \\
\hline & 0.50 & 51.60 & 51.09 & 25.59 & 61.03 & 51.97 & 48.40 & 50.60 & 48.81 & ల్ల & 6.49 & 25.88 & 3.20 & $\mathrm{n} / \mathrm{a}$ & 43.55 & 33.68 & $\mathrm{n} /$ & \\
\hline : & 0.75 & 39.11 & 38.95 & 20.99 & 44.54 & 40.23 & 35.58 & 38.43 & 38.39 & $\stackrel{\mathscr{\Xi}}{\mathscr{G}}$ & $\mathrm{n} / \mathrm{a}$ & $\mathrm{n} / \mathrm{a}$ & $\mathrm{n} / \mathrm{a}$ & $\mathrm{n} / \mathrm{a}$ & 66.10 & 46.90 & $\mathrm{n} /$ & \\
\hline 芯 & 1.00 & 31.60 & 31.78 & 18.38 & 34.68 & 32.52 & 28.95 & 31.42 & 30.56 & $\underset{\pi}{\mathbb{Z}}$ & $\mathrm{n} / \mathrm{a}$ & $\mathrm{n} / \mathrm{a}$ & $\mathrm{n} / \mathrm{a}$ & $\mathrm{n} / \mathrm{a}$ & $\mathrm{n} /$ & & $\mathrm{n} /$ & \\
\hline $\bar{U}$ & 1.50 & 21.33 & 22.73 & 14.41 & 22.94 & 22.47 & 20.62 & 22.80 & 21.92 & $\stackrel{\vec{d}}{2}$ & $\mathrm{n} / \mathrm{a}$ & $\mathrm{n} / \mathrm{a}$ & $\mathrm{n} / \mathrm{a}$ & $\mathrm{n} / \mathrm{a}$ & $\mathrm{n} /$ & & $\mathrm{l} /$ & \\
\hline & 2.00 & 14.09 & 16.09 & 11.33 & 14.21 & 18.28 & 13.61 & 14.61 & 13.98 & & $\mathrm{n} / \mathrm{a}$ & $\mathrm{n} / \mathrm{a}$ & $\mathrm{n} / \mathrm{a}$ & $\mathrm{n} / \mathrm{a}$ & $\mathrm{n} /$ & & $\mathrm{n} /$ & \\
\hline
\end{tabular}

Table 5: Stiffness difference 


\section{CONCLUSIONS}

A three dimensional computational model based on the finite element method of analysis has been developed. The computational model was able to predict the in-plane and out-ofplane behaviour of masonry infilled RC frames containing openings. Use made of the commercial software Atena3D. Within Atena 3D, the masonry infill walls were modelled as an assemblage of stiff yet deformable bricks. Mortar joints represented as zero thickness interfaces. Initially, the brick and interface parameters were determined by carrying out a series of small scale tests. The computational model was then used to predict the in-plane and out-ofplane behaviour of a full scale infill wall panels constructed in the laboratory using a similar brick and mortar combination. From the results analysis, it was shown that the FE model was capable of capturing the load carrying capacity of the masonry-infilled RC frame as well as the different stages of mechanical behaviour of masonry infilled RC frames with sufficient accuracy. Both experimental and numerical results showed that three were two notable features of the behaviour of masonry infilled RC frames. These are: a) initial bed-joint sliding above the opening; followed by $b$ ) diagonal tensile or bed-joint sliding failure at the masonry piers of masonry infill walls. The computational model was also able to capture the load against displacement characteristics of the masonry infilled RC frames with sufficient accuracy. Hence, it has been demonstrated that Atena 3D can be used successfully to predict the in plane and out-of-plane mechanical behaviour of a masonry infilled RC frames with and without opening when subjected to a non-linear static load.

\section{REFERENCES}

[1] CEN. Eurocode 8: Design of Structures for Earthquake Resistance - Part 1: General Rules, Seismic Actions and Rules for Buildings (EN 1998-1:2004). Brussels: European Committee for Standardization, 2004.

[2] W.W. El-Dakhakhni, M. Elgaaly,A.A. Hamid. Three-Strut Model for Concrete Masonry-Infilled Steel Frames. J Struct Eng 129, 177-185, 2003.

[3] Kose MM. Parameters affecting the fundamental period of RC buildings with infill walls. Eng Struct, 31, 93-102, 2009.

[4] P.G. Asteris, C.C. Repapis, L. Cavaleri, V. Sarhosis, A. Athanasopoulou. On the fundamental period of infilled RC frame buildings. Struct Eng Mech, 54, 1175-1200, 2015.

[5] D.J. Dowrick. Earthquake Resistant Design and Risk Reduction. 2nd ed. John Wiley \& Sons Ltd, 2009.

[6] C. Wang, J.P. Forth, N. Nikitas, V. Sarhosis. Retrofitting of masonry walls by using a mortar joint technique; experiments and numerical validation. Eng Struct; 117, 58-70, 2016.

[7] P.G. Asteris, L. Cavaleri, F. Di Trapani, V. Sarhosis. A macro-modelling approach for the analysis of infilled frame structures considering the effects of openings and vertical loads. Struct Infrastruct Eng; 12, 551-566, 2016.

[8] V. Sarhosis, Y. Sheng. Identification of material parameters for low bond strength masonry. Eng Struct; 60, 100-110, 2014.

[9] A. Mohebkhah,A. Tasnimi. Distinct Element Modeling of Masonry-Infilled Steel Frames with Openings. Open Constr Build Technol J, 6, 42-49, 2012.

[10] D. Penava, V. Sigmund, I. Kožar. Validation of a simplified micromodel for analysis of infilled RC frames exposed to cyclic lateral loads. Bull Earthq Eng; 14, 2779-2804 2016. 
[11] D. Penava. Influence of openings on seismic response of masonry infilled reinforced concrete frames. Osijek, Josip Juraj Strossmayer University of Osijek: Doctoral dissertation, 2012.

[12] CEN. Eurocode 2: Design of concrete structures - Part 1-1: General rules and rules for buildings (EN 1992-1-1:2004). Brussels: European Committee for Standardization, 2004.

[13] CEN. Eurocode 6: Design of masonry structures - Part 1-1: General rules for reinforced and unreinforced masonry structures (EN 1996-1-1:2005). Brussels: European Committee for Standardization, 2005.

[14] G. Grünthal, R.M.W. Musson, J. Schwarz, et al. European macroseismic scale 1998. Luxembourg, 1998.

[15] V. Sigmund, D. Penava. Influence of openings, with and without confinement, on cyclic response of infilled r-c frames — an experimental study. J Earthq Eng, 18, 113146, 2014.

[16] M. Tomaževič. Earthquake-Resistant Design of Masonry Buildings. London: Imperial College Press, 1999.

[17] E. Neufert, P. Neufert. Architects' data. 4th ed. Wiley-Blackwell, 2012.

[18] s.r.o. CC. ATENA for Non-Linear Finite Element Analysis of Reinforced Concrete Structures.

[19] M. Hirt, J-P. Lebet. Steel Bridges: Conceptual and Structural Design of Steel and Steel-Concrete Composite Bridges. CRC Press, 2013.

[20] V. Cervenka, L. Jendele, Cervenka J. ATENA Program Documentation Part 1 Theory. Prague: Cervenka Consulting Ltd., 2012.

[21] J.B. Burland, B.B. Broms, V.F.B. De Mello. Behaviour of foundations and structures: state-of-the art report. In: Proc. of the 9th International Conference on Soil Mechanics and Foundation Engineering, Tokyo, Japan, 495-546, 1977.

[22] ATC. Evaluation of earthquake damaged concrete and masonry wall buildings: basic procedures manual (FEMA 306). Redwood City, California, 1998.

[23] V. Sarhosis, K.D. Tsavdaridis, I. Giannopoulos. Discrete element modelling (DEM) for masonry infilled steel frames with multiple window openings subjected to lateral load variations. Open Construction and Building Technology Journal, 8, 93-103, 2014. 